\title{
The Ontario First Nation, Métis, and Inuit Education Policy Framework: A Case Study on its Impact
}

\author{
Laura-Lee Kearns
}

St. Francis Xavier University

\begin{abstract}
In 2007, the Ontario Government implemented the Ontario First Nation, Métis, and Inuit Education Policy Framework. Some schools and school boards have been active in piloting and supporting these initiatives. Because this is a newly implemented policy direction, I wanted to begin to assess best practices and challenges, so I asked participants at one school board and one high school what impact their participation in the Aboriginal education program initiatives had on them professionally, academically, and personally. The Aboriginal programming initiatives, like the ones in which I have participated and studied, have been found to be personally and academically/professionally transformative for administrators, teachers, and youth. As Indigenous-focused curriculum is brought into the mainstream, and as a space is created to consider and include Indigenous perspectives, there is potential for Indigenous and non-Indigenous participants to experience powerful learning opportunities, some of which may transform their perceptions of Canadian history and for contemporary Indigenous people to be valued, though many challenges remain systemically to decolonize the educational realm.
\end{abstract}

Keywords: K-12 Indigenous Education; qualitative research 


\section{The Ontario First Nation, Métis, and Inuit Education Policy Framework: A Case Study on its Impact}

In 2007, the Ontario Ministry of Education released the Ontario First Nation, Métis and Inuit Education Policy Framework. This policy is a foundational attempt to recognize the legacy of colonialism, residential schools, and the state-sanctioned cultural genocide of Aboriginal $^{1}$ people in Canada by forging new relationships and knowledge with and about Indigenous people. In addition to the desire to increase the academic success ${ }^{2}$ of Indigenous youth, there is a vision that "all students in Ontario will have knowledge and appreciation of contemporary and traditional First Nation, Métis, and Inuit traditions, cultures, and perspectives" (Ontario Ministry of Education, 2007, p. 7). The policy statement is ambitious, including among its aims to develop strategies that will "provide a curriculum that facilitates learning about contemporary and traditional First Nation, Métis, and Inuit cultures, histories, and perspectives among all students, and that also contributes to the education of school board staff, teachers, and elected trustees” (Ontario Ministry of Education, 2007, p. 7). The policy directives are broad and far-reaching because they are meant to be implemented inside and outside of the classroom and to involve multiple educational stakeholders.

The multifaceted efforts required to implement and live the policy in Ontario have not reached every school board or classroom (Anuik \& Bellehumeur-Kearns, 2012). Concerns have been raised over educational reforms that focus on Indigenous people across Canada being an extension of assimilationist colonial practices (Comeau, 2005) and over the possibility of aspects of this particular educational policy reproducing a deficit model of Aboriginal people (Cherubini, Hodson, Manley-Casimir, \& Muir, 2010). When taking up a policy, one must consider the epistemological and ethical implications in representing Indigenous knowledge and perspectives in a Eurocentric educational system that has historically shown little understanding of the spiritual, emotional, intellectual, or physical world views of diverse Indigenous people, and that has not acknowledged the impact of colonization and the contemporary social-politicalecological-treaty-rights struggles of Aboriginal people (Battiste, 2002; Donald, 2009a; Haig-Brown, 2008; Kulnieks, Longboat, \& Young, 2011). Historically, the strong tide of a gendered, classed, racialized, heteronormative, and Eurocentric educational system has not only systemically failed to recognize, but also has actively devalued Aboriginal people and their diverse understandings and knowledges (Battiste, 2002; Chandler, 2013; Schissel \& Wotherspoon, 2003). The residential school system in Canada, created to "kill the Indian in the child"3 is the most blatant example (Knockwood, 2001; Milloy, 2006; Regan, 2010). More subtle forms of systemic cultural devaluation also occur everywhere in Canada and throughout Turtle Island (i.e., North America) through the myths surrounding Indigeneity, particularly the ideas that Indigenous people are figures in the past (Caracciolo, 2008; Kearns, 2013; Newhouse, Voyageur, \& Beavon, 2010), and that their homeland, Turtle Island, was devoid of human beings; hence, an empty land to settle (Kearns \& Peters 2013; Loomba, 2008). Additionally, the efforts of some educators to bring Indigenous histories and perspectives to light in the education system have often resulted in a pedagogy of resistance (Schick 2012; Tupper, 2011). 
I want to acknowledge that within the tensions of policy intent and practice, and within the challenges of the legacy of a Eurocentric educational system that continues to enact colonial privilege, spaces have been created that value Indigenous people, which I also recognize as fluid and changing as different people move in and out of these spaces and roles. Despite limitations and imperfections, this study reveals a hopeful space in which one school board and school took small steps towards decolonizing education. In disrupting the Eurocentric narratives, in bringing attention to the perspectives of Indigenous people, and in establishing collaborations between and amongst Aboriginal and non-Aboriginal peoples, a different story with new possibilities is emerging in some educational spaces. By sharing the efforts of this team of players in the educational system and by honouring their words, I will demonstrate that in a space where a full-time Aboriginal education officer and an advisor have been hired to coordinate the policy, and where strong leadership, professional development, resources, and committed professionals exist, and authentic relationships have been built between and amongst Indigenous and non-Indigenous allies, teachers, and students alike, that not only is transformation and change possible, but also efforts to decolonize education and value Indigenous people and perspective have the potential to enrich all peoples' lives.

\section{The Study}

My introduction and interest in the framework grew out of my involvement with it. In January 2008, late in the evening with a 2-month-old baby in tow, I attended a meeting that the local Métis association was also invited to attend; I sat alongside two Métis Elders at the public school board. Here, we were told about the policy framework by an Aboriginal coordinator (former classroom teacher), and Aboriginal education officer (a former teacher and principal), who had been hired and charged with implementing this new initiative. As we introduced ourselves, we learned that there were a number of superintendents, educators, and First Nations representatives present. The coordinator welcomed us all and acknowledged her European heritage, but also explained that she had been trying to live and honour the good red road for a number of years. The tables were arranged in a circle and the importance of Indigenous perspectives and a few teachings were shared with all present. At this first gathering, we were told about the policy and given copies of it. We had the opportunity to discuss some of its highlights, and then we were invited to be part of the Aboriginal Education Advisory committee for the school board. Our small Métis contingent did not know what would come of this journey, but we were intrigued.

As relationships grew and unfolded over the next few years, the Advisory Committee officially changed into an Advisory Circle. Indigenous youth representatives were invited to join. Later, an Inuit mother joined; she had felt alone for 14 years since moving south. I participated in Indigenous Symposiums, Family and Mentorship Nights, Spirit Calling Camps, Think Indigenous Expos at a local high school, professional development sessions offered at different school boards in the province, etcetera, on a fairly regular basis from 2008 to 2011. As an educator and lifelong learner, I must say that these Indigenous-focused educational experiences have been some of the best and most exciting professional development of my teaching career. I was struck by the number of opportunities that resulted from the policy and the people involved in creating 
a supportive environment in this particular school board; it was and continues to be radically different from the previous systemic silencing of Indigenous people that I have experienced throughout my learning and teaching career.

Anecdotally, in conversation with another Métis educator, I mentioned that I had smudged with my Grade 9 English Language Arts class, which I saw as pedagogically appropriate, given an Indigenous character in the novel we were studying. We even made Bannock as the character did in the story. In response, she said that she smudged with her Grade 2 class. What struck me in this exchange was that in over 15 years of teaching, I had never had a conversation like this, nor smudged with a class at a public or Catholic school. My elementary school colleague said that though she had smudged with her class before, she felt that she had to do it very discretely, almost in secret. Now that there is a policy and administrators and teachers are learning about Indigenous people and practices, she did not have to do this "hidden in plain sight" (Newhouse, Voyageur, \& Beavon, 2010). Now that there is a policy that recognizes the importance and difference between Indigenous education, multicultural education, and religious education, sharing Indigenous practices with our students openly is a little more feasible, when appropriate. This shift, albeit small, did seem to create a space that had not existed prior to this work on the Aboriginal Education Advisory Circle and the policy framework.

\section{Method}

Because this was a newly implemented policy framework, I wanted to learn more about the impact this policy direction had on others, beyond short and brief exchanges. After applying for university and school board ethical approval of research, I asked a number of participants in our Advisory Circle whether they wanted to share how the work around the policy had impacted them professionally, academically, and personally. Because I was living outside of Ontario at this point, I was able to meet with a few key interviewees on a short visit: a superintendent, the Aboriginal education officer, and one high school teacher who was teaching the Native studies courses that were being piloted as a result of the policy framework in her school. Through this latter relationship, I visited two classes, and interviewed the youth in two talking circles. The first circle included the teacher, an education assistant, 20 Grade 11 students, and me. A second circle was conducted, which included the teacher, 15 Grade 12 students, and me. From these participants, I further interviewed five students individually, two students together. I also interviewed the high school principal, and the First Nations education liaison for the school. The latter held a number of formal and informal positions with Indigenous and non-Indigenous educational communities: He was a representative on the Aboriginal Education Advisory Circle at the time of the interviews, a frequent guest speaker at the high school in the study (and other schools), a youth mentor at the high school, and was employed full-time as the education liaison for the First Nation community in which he is a member.

In order to explore the experiences of others, I needed a method that was fluid and that would enable me to respond to the participants and their stories. Qualitative research in the form of interviews, observations, and document analysis were the tools used to inform this research (Kvale \& Brinkmann, 2009; Merriam 2002). To seek out people's experiences in a Grade 11 and Grade 12 class, the teacher and I conducted a talking circle 
with the youth, much in the same way a traditional talking circle would be conducted, including the right to pass, but since those usually are not recorded and students do not need to sign consent forms to participate in them, perhaps it is more appropriate to call it a community circle. From those circle talks, and in the time constraints of the class, I was then able to interview five students individually and two youth in a pair (because they asked to be interviewed together). Valuing the words of the participants does not mean an uncritical acceptance of the experiences, but, as Freire (1994) argued, it "implies respect for the 'knowledge of living experience'...on the basis of which it is possible to go beyond" (p. 26). My study of this policy only captures a moment in time, but it is important to have a variety of snapshots revealing the myriad of perspectives in a complicated educational landscape that should and can recognize, value, and honour Indigenous peoples and knowledge.

The semi-structured questions were designed to elicit from participants the professional, academic, and personal impacts of the Aboriginal education program initiatives with which they were involved. I used the term "Aboriginal education programs" in the school setting, as opposed to "the policy framework," to name opportunities that grew out of the policy and Native studies courses, using words that youth understood, and to honour the creativity of dedicated educators who imagined Think Indigenous, the Spirit Calling Camp, and who built relationships and opportunities for the youth to meet and learn from Aboriginal people. Using this term also led to an important story that represents a bridge crossed, after 137 years, by non-Indigenous people to a First Nations community where all the educators in one school spent their professional development day learning from Aboriginal people. That this bridge had never been crossed before was also highlighted as a benefit of the policy by the First Nations education liaison. I present these findings as a case study because the participants are bound in time to the courses and roles they played at the time of the qualitative study, and in a time where I had the time and flexibility to be a participant and an observer. Many of the participants in the study have now changed roles (some of the adult participants have retired or changed positions within the school board and many of the students have graduated from high school) and unfortunately, some funding opportunities have also now ceased. I thank everyone profusely for their generous time and spirit, and for the work they are trying to do on and alongside those who walk the good red road.

Methodological framework. As many critical theorists recognize, if the endeavour to decolonize education is to succeed, then knowledge of and respect for and about Indigenous people by all people on Turtle Island is a necessary component in bringing about change (Kanu, 2011; Roland, 2011; Susag, 2006). There is also recognition of the need to disrupt "White privilege" in the education system (McIntosh, 1990). Smith (1999) argued, in her seminal work on decolonizing methodologies, for the need to deconstruct the past and to story Indigenous knowledges, describing spaces of resistance and hope within a wider framework of self-determination, decolonization, and social justice for Indigenous people. While exploring the voices of my participants, I read their experiences and understandings through a need to disrupt the dominant colonial narrative, to story our past fully, and to be hopeful. For those who engage in the project of decolonizing education, there are challenges and opportunities that come in no equal measure. I have met with support, with passive resistance to outright resistance, and even 
with a White male attempting to take over my university classroom; regrettably, I would say that I personally have met with considerable resistance, in my own journey. However, each space is unique and has different allies at different times. In the spirit of sharing hope and a new story of possibility, and of recognizing that some adults can help transform spaces for themselves and others, specifically youth, I share this multi-layered story (and in this essay space only a glimpse of what happened).

Limitations of the study. This study in no way represents all the school boards or schools in Ontario. Under the purview of the Report on Métis Education in Ontario's K12 Schools produced for the Métis Nation of Ontario, Anuik and Bellehumeur-Kearns (2012) surveyed all Ontario school boards to identify their stage in the process of implementing the policy framework. Results indicated that while some schools and school boards had begun to implement the policy framework, many school boards had not, and there were variations between schools within the same school boards. Also, this particular study sample was small and did not capture the experiences of all participants in the Advisory Committee/Circle, nor some of the nuanced tensions around Indigenous people and representation and voice in a dominant colonial education space. Its design did not enable me to identify whether these efforts were sustained over a longer period of time, something that Indigenous people think is critical for true transformation and change (see, for example, Cherubini \& Hodgson's 2011 work on community consultations and advice from Elders with regard to mainstream education).

There are also concerns over funding cuts and changing roles of some key players; for example, some school boards hired Aboriginal education coordinators for 2 years only and by the time of this writing, these positions no longer exist (personal communication, May 2012). Also, the Spirit Calling Camp ran for 2 years, but it was discontinued after the grants used to help support and pay for the camp space and the Indigenous Elders and community members who worked with the youth were not sustained. Consequently, not all programs that youth participated in that helped transform their learnings about and with Aboriginal people in appreciative ways have been integrated into the educational system on a long-term basis. Given the limits of the data collected, there is certainly a need to continue to examine on-going efforts and relationships and to recognize the systemic challenges, whether that includes creating employment opportunities for Indigenous people, having full-time Aboriginal coordinators at all school boards, or sustained and on-going professional development and other Indigenous focussed opportunities. Still, this case study shows the value of the Indigenous-focussed initiatives given their significant impact.

\section{Findings and Discussion}

The Indigenous to non-Indigenous relationship is complicated; however, within the history and legacy of colonialism in Canadian and specifically, Ontario Education, which has largely ignored or silenced Indigenous perspectives, histories, and cultures, I want to show, by documenting some of the successes, the importance of continued initiatives: initiatives that recognize the importance of questioning colonial narratives about Canadian history, that are committed to on-going professional development opportunities, that focus on relationship building between Indigenous and non-Indigenous people, that help to build the capacity of Indigenous allies, and that value Indigenous 
knowledge, perspectives, and people. From interviews, community circles, observations, and my own participation in various aspects of the Ontario First Nation, Métis and Inuit Education Policy Framework, I present some of the findings from a diverse range of participants, from the school board level to the classroom. In the "Living the Policy at the School Board Level” section of this paper, I share how a superintendent and an Aboriginal education officer, who alongside the Aboriginal education coordinator and teachers and other school board employees, engage with the policy framework. In the "Living the Policy in School," section, I share a specific story of one high school in a settler community that is located beside a First Nation community, but is separated geographically by a small body of water and by a bridge, and some of the educational changes, personally and professionally, experienced by a First Nations education liaison, a principal, an educator, an education assistant, and some students. Though more stories and facets of the narratives could be told, I have shared only enough to illustrate how various people can be involved in transformation and change personally and professionally in various ways and at different levels in the educational system.

\section{Living the Policy at the School Board Level}

The policy document has created spaces and impacted people differently because of the way it was engaged with and because of who was working with the possibilities presented within the framework. When I asked one of the school board superintendents in the Aboriginal Advisory committee, about her engagement with the framework she said:

When you get a document like that, it is very important to begin to look at doing a self- assessment. Where are we and where do we need to go?...It's a slow process...even though we have a lot of things in place, until you actually gain the trust of the Aboriginal community, you're never going to...move along. (interview, May 20, 2010)

At the level of engagement, the superintendent recognized that for the policy to begin to be enacted, the policy had to be read and reflected upon. Further, those who worked in school boards must ask themselves what has been done and what needs to be done. Most importantly, relationships needed to be built between Indigenous and non-Indigenous people to move the policy forward.

The superintendent noted:

It's really sad that it took a policy to actually mobilize this...that it wasn't a natural evolution because Indigenous people are of this land; they preserved it....It's unfortunate that we as a group never really...[made connections to Aboriginal education/people]...until some of the meetings at the [Ministry of Education]... [about the] 2007 policy document. (interview, May 20, 2010)

With frank sincerity, the superintendent was recognizing the very real educational privilege of the dominant culture that failed to see and engage Indigenous people. First Nation, Métis, and Inuit peoples became visible to some in positions of power only because a policy was created and discussed.

When asked about personal connections, the superintendent shared: 
Sitting with the Advisory Circle has been really good because [our facilitator] is someone who is very knowledgeable and connected, and is very passionate about it. And if you talk to anyone in our department about it when [you] leave the meetings, [you] come out feeling a lot more peaceful and good about things. At the end of the day, it's 6 or 7 p.m. you've worked since 7 a.m., [and you] usually feel so tired, going into meetings... You think, oh yeah, I have the Aboriginal Circle meeting tonight and even if [you] are exhausted ... when you come out (of the Aboriginal Circle meeting) you feel really good and come out not feeling tired....The circle and practices and presentations are really good. (interview, May 20, 2010)

The sharing and learning from the Circle connections were personally energizing and enriching for the superintendent. The Advisory Circle is facilitated by a fulltime Aboriginal education coordinator, as well as officer, who are dedicated to sharing Indigenous focussed teachings and practices at every gathering. The superintendent continued on, saying that she is learning so much:

One of the Moms did a presentation on her culture [Inuit culture] and she is very proud of it. After it is over, we are all sitting there saying, "Wow, you know, we didn't know.” For me it's been a great experience; there is a lot more to learn; there is a lot more work to be done. (interview, May 20, 2010)

The superintendent noted that since the school board has begun to implement the policy and build relationships with First Nations, Métis, and Inuit people, "I've become educated, far more aware...I didn't think I was being disrespectful; that's because I didn't know” (interview, May 20, 2010). From her discussion, it is clear that the impact of learning about the experiences and perspectives of Aboriginal people has been enriching, personally and professionally, that there is recognition, and that there is so much more to learn. The relationships were purposely built by the people appointed to live out the policy, build relationships, and reach out to community members who helped create a space for new knowledge with regard to Aboriginal presence. The role of the Aboriginal community members has been integral in helping educators enhance their understandings and recognize that they were not aware; it is beginning to help many educational stakeholders learn about that which they did not know because of their own privilege and colonial education.

\section{Working to Decolonize Education}

The Aboriginal education officer, when discussing the importance of professional development for teachers and staff, made a concerted effort to begin with helping nonIndigenous people gain greater understandings and recognize their position of privilege:

We are...focussing on cultural proficiency [about Indigenous people].... If you live in a dominant culture, then everything around you validates what you think and feel.... You don't feel... you are biased or [that you] hold stereotypes or [that I] am prejudiced or anything because everything around you validates everything you feel, all the ways you'll react. But you live in a bubble, like we did in the school system. We were protected, Canada the good; now I am not saying...Canada is a wonderful country... but we were protected. We are trying to 
allow people to recognize the environment they grew up in, and take a step back and reflect on it..."Wait a second! This is the way I always heard things; I developed a bias without even knowing it." (interview, May 18, 2010)

Certainly the first need is recognition. Newhouse (2010) has written that Indigenous people are "hidden in plain sight." They/we have always been here, as the superintendent stated, but they/we were not recognized. The dominant culture sustains the myth of the unsettled land. So, confronting the legacy of colonialism's narratives and of systemic silence is paramount to creating the space for the policy to have life. Further, it is important to identify how people continue to be privileged, to benefit from colonialism, and fail to recognize Indigenous people and perspectives.

\section{Living the Policy in School}

\section{Crossing a 137-Year-Old Bridge}

The school in the settler community I visited was 137 years old at the time of the interviews. It is uniquely situated next to a First Nations community. The communities are visually divided by water and linked by a road bridge. When I asked the First Nations education leader about changes that had taken place since the policy had been implemented, he said:

I did not have a very good relationship with the previous administration of [school $\mathrm{X}$, [but] when the new administrator came in she was so supportive. She said "go to it" and she stepped back. And then, we started to look at what we could do with the teachers because we knew we had to create awareness amongst the other teachers. The Native studies teacher saw straight away that the policy initiative was to infuse Aboriginal components right across the curriculum. She spoke to the principal and we came up with the thought of a PD day out at the island. We will take the teachers right out of the school and we will have Native studies brought to the teachers. It was a whole day. ${ }^{4}$ (interview, May 19, 2010)

In a separate interview, the school principal also said that the relationship prior to the initiatives brought forth by the policy through the particular people trying to live them was not collaborative. The principal said:

There was not a great relationship or certainly not much of a connection between the High school and the folks on the island. The First Nations education liaison and I made a connection, I really appreciated his passion and really liked the work he was trying to do.... I just wanted to find out how I could help in making an easier transition for our First Nations kids in our high school and [in] recognizing that there are different needs in the communities and [that] these are our kids, and [consider] how to best serve them. (interview, May 3, 2010)

This particular principal had spent some time in an Inuit community 20 years earlier. She was able to form a different relationship with the First Nations education liaison. When the idea for the professional development day came about for the teachers, she was fully in support. Because the principal recognized and supported the need to train all the teachers, she commended the First Nations education liaison and the high school Native 
studies teacher, "who put it all together," for their work together in enhancing relationships, adding:

It was something in the Aboriginal education liaison's heart [that] he had always wanted to see some day, and it happened pretty quickly and I think he was really amazed at how powerful it was, and it was probably one of the best PD days we've ever spent. It was certainly one of the best for this staff. They thought it was one of the best days they had ever spent learning. They came back just pumped. Teachers who really hadn't thought about teaching Native studies said, "You know I can put a lot of this in what I do." That's what came out of it. It's been really powerful. The relationship has been really close, really positive, a wonderful partnership with the First Nation community. (interview, May 3, 2010)

For a mostly non-Indigenous staff, the learning from First Nations people was incredibly powerful. The historic divide was bridged a little more, not only physically, but also by those who saw and heard stories or experienced moments of transformation. The First Nation educational liaison was really struck by many non-Indigenous educators were moved to "tears" in their own talking circles at the end of the day (interview, May 19, 2010).

The Native studies course and the educator who facilitates the course have been integral in the efforts to reach out to First Nations community members. In the first year of the Native studies course offered at the high school, the classroom teacher and a student teacher helped shape what has now become known as the Think Indigenous Expo. According to the First Nations education liaison, the Chief and Council were invited and attended, alongside over 1,000 people. He said,

It was fantastic...From a school in [this location], which was very ethnocentric, this school has moved to one with diversity as a result of Aboriginal Education. The whole basis of Aboriginal education is now meeting [a lot of] the other goals that we see in school, and I think it is just absolutely wonderful. (interview, May 19, 2010)

The principal also echoed,

[There has been] transformation...there were some really marginalized kids that felt invisible, [and] now they are not like that anymore; they are a part of it; this is their school; they feel welcome [and] that we see them, and they see themselves along the wall and in the stuff being taught. It's just wonderful, so enriching. (interview, May 3, 2010)

It is evident from the principal's experiences that there has been a shift professionally and personally for many of her staff members and for youth in the school. The First Nations education liaison witnessed transformation of educational staff, and noticed a difference for some First Nations youth, as well. He shared:

There is [the story of] one boy who is autistic. This is an amazing thing. Part of the Native studies course that year was to go to the canoe museum. [There], the students were given the opportunity to make a soapstone carving. This one young boy took his soapstone carving... [and made a carving, and in viewing the final 
product] this was the first time they [educators and classmates] were able to see his abilities [and his artistic potential]. So they got him another piece of soapstone. He looked at it, was turning it [when] he dropped it on the ground and it broke up. He looked at the pieces, took each one, and started carving. [By the time] the Think Indigenous EXPO [was held at his high school], he had his own display table where he carved. [He] had people coming up to him [to] watch him carve. And he sold his pieces...I think he made \$1,300. The students were helping a student in Africa to complete this electrical program and this boy gave this money to this cause. This young autistic man won the student of the year award. His mother came to [his teacher and student-teacher], [and] she was crying, and she said, "You have given me back my son." This is the type of thing we see in Aboriginal education. Aboriginal education has so many facets and so many philosophies of [how] to reach students. I think Aboriginal education is holistic; it reaches all the abilities that individuals may have. (interview, May 19, 2010)

Clearly, the educator who used cultural community connections - the canoe museum-to enhance the curriculum for her students had enabled the young people in her class to connect deeply to untapped talents. The connections and spaces created as a result of Aboriginal education has had a meaningful impact on many. Through Aboriginal education, one is able see the whole child, with the family, the teachers, the principal, and the First Nation education liaison all caring for and talking about the child, creating a nurturing community.

The First Nations education liaison has seen a lot of power and possibilities in the education system; yet, he also was aware of the challenges that come with the opportunities. He said:

It begins with the classroom teacher; they have control of their curriculum.... We [see] teachers who are reluctant to talk about Aboriginal issues because they [are] afraid, they want to be politically correct, and [they] are not going to teach something with which [they] are uncomfortable or something [they] don't know anything about. We have said that First Nations within the Board's jurisdiction ought to be part of the process, to assist teachers to do their jobs. When [we] start to be an active partner, then we are going to start to learn. I think it is all in partnering; it is [on the] basis of the community partnering because education is the basis for the future, for all people to move on and develop. We need support of all the senior administration in the boards....we need awareness at the higher levels....The value and support of Aboriginal communities to the school system cannot be understated by mainstream culture if public schools are going to meet the needs of Aboriginal learners and help all students and teachers learn about and alongside Aboriginal peoples. (interview, May 19, 2010)

In the Native studies classrooms. The youth voices emerging from the study are remarkable. They tell stories of empathy, power in knowledge and knowing about Canadian history, a commitment to transformation and change, and, for Indigenous youth, a connection to pride and spirit. The efforts of the educator who has been working tirelessly to develop these courses cannot go unrecognized. As with any first time course that is being developed, it is not perfect, but it gets better with time, more so as she 
learns, as well. She said what helped her with the courses was the support she received from the First Nations community. She often consulted and talked and developed a strong personal and professional working relationship with the First Nations education liaison; she said:

I also said to my First Nations community...if I am doing something wrong, I need you tell me and put me on the right track. I need to be the bridge between the two communities; I need to make sure that your voice is heard. (interview, May 2, 2010)

By showing that knowledge is constructed, by risking to learn and to teach, and by acknowledging that she does not know everything and is learning, she demonstrates her desire to honour and create a space for First Nations, Métis, and Inuit voices.

As a history teacher who has made a practice of hearing marginalized stories, her experiences have enabled her to realize that there are many stories Canadians do not know or want to know about. She stated:

I've learned through projects that I've done in the past... with veterans and the work that I've done with them...it has shown me that there are battles that Canadians don't want to face. Our first reaction is to say it didn't happen or just ignore it. We have to stop doing that... at some point you just have to face it. (interview, May 2, 2010)

There are several battles between Indigenous and non-Indigenous people that have taken place as well, and this is something she wants her students to recognize. She has asked her students to imagine pre-settler society and the impact of 500 years of colonialism and residential schools, and to consider the resilience and the "miracle that Aboriginal people are still here today” (Teacher, interview, May 2, 2010).

In the talking circle, she shared with her students that she is also someone who is working hard to create an excellent course and experience for the students, and she is working with and alongside Indigenous people and she herself is learning and refining her perspective:

I was just going to say that as far as my practice as a teacher goes, and I'm trying to give you [the students, in the talking circle] varied experiences, I felt what I did, or tried to do is teach you what I knew, but then bring [in] somebody that is from an Indigenous culture. So, when a First Nations speaker came to class, you were actually listening to her, [and] it enhanced your knowledge, [even though] it wasn't new; the four medicines weren't new when she came in, but then you got to use it and participated in the ceremony she did with you....I used to think...all Aboriginal people, in order to be healthy, had to go back to the "Old Ways," but this year I have totally changed my philosophy on that; I learned they have to regain their "Life Ways," which is how they perceive the world...it's not old, it's a continuation of how they feel today...I think [in] their culture, [in] their languages, we need to assist them in preserving that; we don't need to tell them what to do, but we need to pass laws that assist them. We need to respect what 
they are doing... I think we need to be partners in that; we need to be partners because this is what Canada is. (Talking Circle, May 3, 2010)

By positioning herself as a bridge between First Nations people, knowledge, and the Canadian curriculum in her school that she wants to bring to life in a respectful and honest way, she has created an enriching environment for her students in which to thrive. The students in her classes shared many incredible stories-from the heartbreak of learning about residential schools, to working on the project of the heart tiles, to writing to the government about contemporary issues and injustices that they perceive.

The voices of youth learning about Canadian history. Many youth seemed empowered by learning about Indigenous people and learning from Indigenous people. Many of the youth in the study remarked that they felt it was important that they learn about our actual histories. One Grade 11 youth said:

I came into this class and didn't know what it was all about, but learning so much about what really happened [to Native people]... it's part of our history; we should all really know about. Maybe if we learn about it, we could prevent it from happening again. (Female Student \#8, Talking Circle, May 3, 2010)

Another Grade 11 youth added:

I like this course, it teaches us things we didn't even know. It reminds me of the people who say the Holocaust didn't even happen. We did way more than that to First Nations... [and those of] different cultures and stuff, like what happened to the Japanese people in the war; it's just good we don't cover it up. You've gotta know your history. (Male Student \#3, Talking Circle, May 3, 2010)

These youth recognize that events on Indigenous territories that have taken place for hundreds of years are part of everyone's history in Canada. They have narrated past the lack of recognition a large majority of Canadians have with regard to the stories of violence and genocide experienced by Indigenous peoples as a result of colonialism. In considering the atrocities committed against Indigenous people, the teacher and several students referenced the old adage "Those who cannot remember the past are condemned to repeat it" (Santayana, 1905, p.284). They recognized that we need to know what happened to ensure we do not continue to re-inscribe a colonial state. There is also a sense of learning and a respect that was weaved throughout the discussions. As one Grade 11 youth said: "I like that we learn about our past, about what happened in our country, that we honour our past, [and] the First Nations people” (Female Student \#3, Talking Circle, May 3, 2010) And a Grade 12 student added: “I look at other countries' histor[ies] and then ours and it's good to see what a rich history we have here in Canada. It’s good to explore this history” (Male Student \#2, Talking Circle, May 3, 2010).

Advocacy and voice. The education assistant who witnessed the teacher and students passionately engaged in Native studies and Canadian history recognized, "It's been hard work to put this course together [on the part of the teacher]; there is no work in the past that she can draw on" (Education assistant, interview, May 3, 2010). Students recognize and appreciate the course: "I love all the Art and Crafts the movies we watch, the slides, the little tests” (Grade 11, Female Student \#5, Talking Circle, May 3, 
2010).One of the learning experiences the teacher shared about putting these courses together is that "you look at the significant moments and you learn that Canadian history is complex and that there was a lot of violence and horrible things happened, such as residential schools...[and this can be very heavy, disturbing and even depressing for youth]" (interview, May 2, 2010). In the second year of the courses, the educator recognized that youth had to be able to do something positive after all of their learning. Because of this attentive pedagogy, many youth commented on how important and powerful it was to be an ally and advocate. As a class, they were encouraged to write letters about issues they were passionate about with regard to Indigenous people. One youth said she wrote the government “...about residential schools...first of all [being] unacceptable. I can't wait to hear back from the frigging Prime Minister about my letter!” (Grade 11, Female Student \#7, Talking Circle, May 3, 2010). Another youth said: "I feel like we do stuff that isn't about us, with the tiles and how we wrote letters to the government and stuff. We can really get involved with our community, serve our community, make our community aware” (Grade 11, Female Student \#9, Talking Circle, May 3, 2010). The tiles to which the youth is referring are from the experience of the class participating in the Project of Heart. ${ }^{5}$ Youth, once informed and given support, do want to be allies, actively engaged with and working alongside Indigenous people, as well as learning from Aboriginal peoples.

Personal impacts: Understanding, questioning, navigating a more respectful life. In many of the youths' estimations, the most powerful learning experiences, ones that have even been transformative, have come from their engagement and learning from Indigenous peoples themselves. One of the Grade 12 students reflected:

For me learning all this, the history of what actually took place instead of an incorrect version that was always told to us, to know the facts, to really learn, it has made me a really accepting person. I also really love learning the traditions, the way the Aboriginal people treat everything, including the earth. It's made me want to live my life in a more respecting, giving way. (Female Student \#1, Talking Circle, May 3, 2010)

The course includes history, but also has Elders, Indigenous community members involved with the youth and sharing a variety of teachings from Indigenous worldviews. For this non-Indigenous youth, the impact is clear. Another Grade 12 student added:

I think that after taking this course, if I run into a native person and we have a conversation I would be able to know what they are talking about now, the history. And if I run into a person who holds a stereotypical view of Aboriginal peoples, I would be able to help correct them now. By completing this course and realizing how Aboriginals treat the earth and animals, even I look at things a little bit differently now. What am I doing? How can I help keep the earth the way it is? (Male Student \#6, Talking Circle, May 3, 2010).

Another youth added:

This is a very interesting course. I had a bit of a background because people in my family have studied Native culture. I am almost to the point where I will be out on my own and this course really made me think about how I want to live my life, 
about what I buy, or need or don't need. We always think about a civilization by what it leaves behind; well, it's extra important when we look at Native culture...they have been able to leave nothing behind. In the future, I will be looking into what politicians believe when it comes to Aboriginal stuff, and not voting for racist policies and such, so it's definitely been an eye opening experience. (Grade 12, Male Student \# 7, interview, May 21, 2010)

The youth in this study attested to being transformed to ask questions about the hidden histories, stories, cultures in Canada, and examining bias and stereotypes, and seeing themselves as people who can help change these mistaken perceptions. They also acknowledged they were impacted by the Indigenous people and their teacher, and stimulated to ask questions about their own lives and how they want to live and what they value.

One wonders if these efforts are sustainable. One youth described the courses, learning, and the impact of Indigenous knowledge in mainstream education as follows:

I think it's the start of something so new, everyone wants to be a part, almost like a new product that hits the market, so I think everyone thinks that. You know, it's brand new, getting involved in our world and our curriculum and I think everyone is just going to want to be a part of it...to be the new craze. I think that's what the whole thing is about. It's not something that is going to die out, like someone seeing the first product at school and after 2 months ...it's going to be in the closet, it's going to last ...for a very long time, and like I said it's a very important part.(Grade 12, Male Student \#5, interview, May 21, 2010)

For non-Indigenous youth, there are clearly significant benefits to seeing a bigger Canadian story, of which they are a part. For all of us as Canadians, it is in all of our interests to develop better relations now and into our common future.

Opportunities for connection and pride. Indigenous youth have been positively impacted by the experiences that came about through the Indigenous focussed initiatives. Thinking back, one First Nation student said that the Think Indigenous Expo provided an opportunity to share and have Indigenous history and contemporary identities recognized in schools. The result was powerful: "I am more proud of myself" (Grade 11, Female Student \#6, interview, May 3, 2010). One student, a Métis who did not grow up with the culture, talked about the impact of participating in the Spirit Calling Camp. With a big smile on her face, she proclaimed: "I danced and I never dance" (personal communication, May 28, 2010). And another youth who has Indigenous ancestry, but who does not live with her Indigenous parent on a full-time basis, said the course really helped give her some language and experiences and tools to connect more deeply with her parent:

I really love this course... Now every time I see [my mom], we talk about this course. We actually do some of the things we do here... I ask, can we smudge, mom?...It reconnects us, now that there is some sort of background there now... it's not like a normal class where the teacher doesn't care about what they are saying. Whether you pass or not. (Grade 11, Female Student \#4, interview, May 3, 2010) 
The voices of these youth show how deeply personal and transformative the opportunity to learn more about and with Aboriginal people is. In some youths' experience it has meant rebuilding familial relationships through the reacquisition of personal history and culture. Though all people are impacted by colonialism in different ways, and though many Indigenous people are resilient and have been deeply connected to Indigenous spirituality and knowledge, those who have journeyed differently in a colonial education system, creating spaces where Indigenous people are valued, cannot be underestimated.

Reason for hope. The education assistant who has moved from class to class observing what students have said over the years had this to say about the Grade 11 class when she participated in the talking circle: "I really appreciate this class, for the students, for their openness" and added, "[They] will be a group of people that can force change and policy decisions” (Talking Circle, May 3, 2010). The texts, experiences, community connections, and dedication of a passionate teacher, of Elders, and of Indigenous people have helped create a space for youth to learn, share, and grow, and has given them tools for their lives. The youth themselves have welcomed all the opportunities to engage with Aboriginal focussed curricula and Aboriginal peoples. The potential for transformation and change is certainly taking root in some educational spaces.

\section{Reflections}

The voices in my study show that much is not known about our colonial, Canadian history. Work in bringing this to light is important in order to create a space for Indigenous knowledge and perspectives in the curriculum and educational system. As Cherubini and Hodson (2011) argued, "colonization is not a reality of Aboriginal peoples alone. Instead, colonization continues in contemporary times and limits all peoples” (p. 173). It would certainly be a mistake to curtail efforts that bring forth awareness, understanding and appreciation of Aboriginal knowledge, perspectives and people, as the policy framework stipulates. Kanu (2011) maintained that when we value Aboriginal perspectives across the curriculum for all people, it is not only inherently valuable for Aboriginal people, but also increases everyone's funds of knowledge, and will hopefully begin to redress historical misrepresentation and identity-damaging curriculum for and about Aboriginal people.

Aboriginal knowledge is not only valuable in the past, but is also significant in the present. It has the potential to help Aboriginal and non-Aboriginal youth affirm the importance, vibrancy, and relevancy of claiming one's Indigenous heritage and identity. It also has the potential to awaken one's own lack of understanding with a desire to learn more because the wisdom of traditional practices is applicable for all people. Donald (2009b) wrote that the process of decolonization requires all people to actively deconstruct "their shared past, and engage critically with the realization that their present and future is similarly tied together" (p. 5). We need to recognize the past, to acknowledge Indigenous perspectives, and to build relationality in the present so we can consider our collective future.

The stories that I have shared attest to the possibilities of transformation and change, and hope for decolonizing education. Integral to the work is having designated people working in the education system as a first contact for Indigenous people, such as 
education advisors and coordinators, facilitating workshops for staff at all levels, advisory circles, and work that supports what educators can do in classrooms for and with youth. Certainly, more work needs to be done, more relationships need to be build, and more knowledge needs to be storied in respectful ways. But if more youth and educators learn about Aboriginal Canadian history and feel positive about Indigenous teachings and practices, perhaps transformation and change in the educational system is possible.

\section{Conclusion}

The Aboriginal programming initiatives like the ones I studied have been found to be personally, academically, and/or professionally transformative for administrators, teachers, and youth. As Indigenous focused curriculum is brought into the mainstream, and a space is created to consider and include Indigenous perspectives, there is potential for Indigenous and non-Indigenous participants to experience powerful learning opportunities, and to transform perceptions about Canadian History. Although many systemic challenges remain for all contemporary and historical Indigenous people to be valued, new educational spaces are emerging that signal an important shift in changing the dynamics of the legacy of colonial education and mis-education. The road is long though, as many educators and school boards have not begun this journey and are not aware of the Ontario First Nation, Métis and Inuit Education Policy Framework and its multifaceted aims for Indigenous and non-Indigenous people. Still, policy may represent a crack where the light gets in (Cohen, 1992) when individuals work together and support each other to create educative spaces. After enduring years of shame, silence, and systemic racism (Schissel \& Wotherspoon, 2003), First Nations, Inuit, and Métis perspectives need to be part of the official curriculum not only in Ontario, but also across Turtle Island. In the tension-filled spaces of public education, I want to acknowledge some of the seeds that have been planted; they still very much need to be tended so they begin or continue to grow and these seeds will also need to be nourished so that their roots grow stronger. Perhaps, ultimately, new soil will be needed to bring about real epistemic transformation, but within the existing soil, a few plants have had a few more opportunities to thrive than they would have otherwise. My hope in sharing this is that others may also begin to sow seeds to begin the important work of valuing Indigenous presence in multifaceted ways. 


\section{References}

Anuik, J., \& Bellehumeur-Kearns, L-L. (2012). Report on Métis education in Ontario's K-12 schools. Report for the Education and Training Branch, Métis Nation of Ontario. Retrieve from http://www.metisnation.org/media/246898/anuik\%20kearns\%20métis\%20educati on\%20in\%20ontario\%20report\%20final\%20draft\%202012\%20\%5B3\%5D.pdf

Battiste, M. (2002). Indigenous knowledge and pedagogy in First Nations education: A literature review with recommendations. Report Prepared for the National Working Group in Education and the Minister of Indian Affairs Indian and Northern Affairs Canada (INAC). Ottawa, On: Canada. Retrieve from http://www.afn.ca/uploads/files/education/24._2002_oct_marie_battiste_indigeno usknowledgeandpedagogy_lit_review_for_min_working_group.pdf

Caracciolo, D. (2008). Addressing anti-Indianism in the mainstream curriculum: A partnership model. Multicultural Perspectives, 10(4), 224-228. doi:10.1080/15210960802526318

Chandler, M. (2013). Indigenous education and epistemic violence. CEA Canada Education Association, 53(2). Retrieve from http://www.ceaace.ca/education-canada/article/indigenous-education-and-epistemic-violence

Cherubini, L., \& Hodson, J. (2008). Ontario Ministry of Education policy and Aboriginal learners' epistemologies: A fundamental disconnect. Canadian Journal of Educational Administration and Policy, 79.

Cherubini, L., \& Hodson, J. (2011). Heightening awareness and strengthening relationships: Implications of public policy for Aboriginal students, communities and teachers. In J. Reynold, W. S. Gilbert, \& L. Lockard (Eds.), Honoring our heritage: Culturally appropriate approaches for teaching Indigenous students (pp. 173-195). Glagstaff, AZ: Northern Arizona University.

Cherubini, L., Hodson, J., Manley-Casimir, M., \& Muir, C. (2010). 'Closing the gap’ at the peril of widening the void: Implications of the Ontario Ministry of Education's policy for Aboriginal education. Canadian Journal of Education, 33(2), 329-355.

Cohen, L. (1992). Anthem. The Future. New York, NY: Columbia Record Albums.

Comeau, L. (2005). Contemporary productions of colonial identities through liberal discourses of educational reform. Journal of the Canadian Association for Curriculum Studies, 3(2), 9-25.

Donald, D. (2009a). The curricular problem of indigenousness: Colonial frontier logics, teacher resistances, and the acknowledgement of ethical space. In J. Nhachewsky \& I. Johnston (Eds.), Beyond "presentism": Re-imagining the historical, personal, and social places of curriculum (pp. 23-39). Rotterdam, Netherlands: Sense Publishers.

Donald, D. (2009b). Forts, curriculum, and Indigenous Métissage: Imagining decolonization of Aboriginal-Canadian relations in educational contexts. First 
Nations Perspectives: The Journal of the Manitoba First Nations Education Resource Centre, 2(1),1-24.

Freire, P. (1994). Pedagogy of hope. New York, NY: Continuum.

Haig-Brown, C. (2008). Taking Indigenous thought seriously: A rant on globalization with some cautionary notes. Journal of Canadian Curriculum Studies, 6(2), 8-24.

Kanu, Y. (2011). Integrating Aboriginal perspectives into the school curriculum. Toronto, ON: University of Toronto Press.

Kearns, L. (2013). The construction of 'illiterate' and 'literate' youth: The effects of highstakes standardized literacy testing. Race, Ethnicity and Education. doi:10.1080/13613324.2013.843520

Kearns, L. (2013). (Re)claiming Métis women identities: Three stories and the storyteller. In C. Adams, G. Dahl, \& I. Peach (Eds.), Métis in Canada. Alberta, Canada: University of Alberta Press.

Kearns, L., \& Peters, N. (2013). (Re)inscribing Mi'kmaq presence through public petition, performance and art. In S. Ashley (Ed.), Diverse spaces: Examining identity, heritage and community within Canadian public culture. Newcastle upon Tyne, United Kingdom: Cambridge Scholars.

Knockwood, I. (2001). Out of the depths: The experience of Mi'kmaw children at the Indian Residential School at Shubenacadie, Nova Scotia. Black Point, Canada: Fernwood.

Kulnieks, A., Longboat, D., \& Young, K. (2011). Indigenizing curriculum: The transformation of environmental education. In D. Stanley, \& K. Young (Eds.), Contemporary studies in Canadian curriculum: Principles, portraits, \& practices. Calgary, Canada: Detselig.

Kvale, S., \& Brinkmann, S. (2009). interviews: Learning the craft of qualitative research interviewing. Sage Publications, Incorporated.

Loomba, A. (2008). Colonialism/Postcolonialism. New York, NY: Routledge.

McIntosh, P. (1990). White privilege: Unpacking the invisible knapsack. Independent School (Winter).

Merriam, S. R. (2002). Qualitative research in practice. San Francisco, CA: Jossey-Bass.

Milloy, J. (2006). A national crime: The Canadian government and the Residential School system 1879-1986. Winnipeg, Canada: The University of Manitoba Press.

Newhouse, D. R., Voyageur, C. J., \& Beavon, D. J. K. (2010). Introduction. In D. R. Newhouse, C. J. Voyageur, \& D. J. K. Beavon (Eds.), Hidden in plain sight: Contributions of Aboriginal Peoples to Canadian Identity and Culture (pp. 3 13). Toronto, Canada: University of Toronto Press. 
Ontario Ministry of Education. (2007). Ontario First Nation, Métis and Inuit education policy framework. Toronto, ON: Author. Retrieved from http://www.edu.gov.on.ca/eng/aboriginal/fnmiFramework.pdf]http://www.edu.go v.on.ca/eng/aboriginal/fnmiFramework.pdf

Regan, P. (2010). Unsettling the settler within: Indian residential schools, truth telling and reconciliation in Canada. Vancouver, BC: University of British Columbia Press.

Roland, K. (2011). Creating inclusive space for Aboriginal scholars and scholarship in the academy: Implications for employment equity policy. Canadian Journal of Educational Administration and Policy, 118.

Santayana, G. (1905). Reason in Common Sense, volume 1, The Life of Reason. Wikipedia

Schissel, B., \& Wotherspoon, T. (2003). The legacy of school for Aboriginal people: Education, oppression, and emancipation. Don Mills, Canada: Oxford University Press.

Schick, C. (2012). White resentment in settler society. Race, Ethnicity, and Education. 115. doi:10.1080/13613324.2012.733688

Susag, D. (2006). Why Indian education for all? Through our own eyes. Phi Delta Kappan, 88(3), 201.

Smith, L. T. (1999). Decolonizing Methodologies: Research and Indigenous Peoples. London, England: Zed Books.

Tupper, J. A. (2011). Disrupting ignorance and settler identities: The challenges of preparing beginning teachers for Treaty education. In Education, 17(3). Available from http://ineducation.ca/article/disrupting-ignorance-and-settler-identitieschallenges-preparing-beginning-teachers-treaty-e

\section{Endnotes}

${ }^{1}$ I use the term Aboriginal in keeping with the Ministry of Education definition for First Nation, Métis, and Inuit; I recognize that this is sometimes a contested term as most Nations want to be known by their specific Nation. I do also use the term Indigenous throughout the paper to signal Aboriginal peoples

${ }^{2}$ It is important to recognize that educational discourse often frames Indigenous peoples' success or lack of success within colonial standards of measurement, thus creating a deficits discourse around Aboriginal peoples' identities without looking at the power relationships that construct deficits or questioning the norms around which people are assessed (Battiste 2002). Concerns over this policy intent and the standards of measurement that could reduce success to a test score have been raised (see Cherubini \& Hodson 2008, for example), and elsewhere, I have written about the reproduction of colonial power through standardized test measures (Kearns, 2013). I do not want to 
minimize these concerns in any way; furthermore, the absence of most school boards participating in the spirit of the policy (see Anuik \& Bellehumeur-Kearns 2012 report) speaks to the larger issue of a broad range of strategies that are needed to begin to decolonize and transform education with, for and about Indigenous peoples, but within this paper I do want to highlight a glimmer of hope

${ }^{3}$ See, Duncan Campbell Scott:

http://en.wikipedia.org/wiki/Duncan_Campbell_Scott\#cite_note-7

${ }^{4}$ The First Nations education liaison describes the workshop as follows: "We had four workshops which we didn't run concurrently; teachers chose their workshop. We had one on governance, as many people wonder or are not sure how First Nations are governed so we had Chief and Council, the Administrator, and we had a panel, and teachers came to that. There is always the question of religion. We have to keep religion out of the classroom but for Aboriginal people, that is impossible because we are spiritual people, not necessarily religious people, but very much connected to the land and spirit and so spirituality is a big thing. So we decided to have a workshop showing the spiritual connection between humans, animals, and the planet world. We had the caterer come in and she did the workshop on that topic because she offers workshops. We had another workshop on culture, another with environmental studies, will and the final workshop was on crafts and how to incorporate crafts into the curriculum. She was a trained teacher. All Aboriginal people did the workshops--First Nations people. The teachers came. We took them out of their comfort zone. Teachers are used to writing so at the end of the day, they will still want to write, so the evaluation process still be paper and pen. But what we thought we would have them do is to use the talking stick and bring it into circles. The students themselves [at the high school] made the talking sticks for the teachers to use and this was amazing. There were 125 teachers who broke up into ten circles. Each teacher was able to express verbally what they thought about the day. It was unbelievable! It was so powerful! The Director of Education, [name withheld], came to that part and he was amazed. There were two teachers in particular who were large men, not stout or anything, they looked like football players, I don't know if they were Phys. Ed. teachers or not, but they were so moved that they were in tears. That was unbelievable. The Principal would go from group to group to get a sense of how the teachers felt. It was unbelievable. They couldn't believe what they had heard. For some it was their first exposure and they wanted more of this.”

${ }^{5}$ Project of Heart: http://poh.jungle.ca/4-partner-commitment 